\title{
AVRUPA TOPLULUĞU HUKUKUNDA İPTAL DAVASI VE ÖZEL KISȘILERIN DAVACI OLABİLME KOŞULLARI: TOPLULUK İÇTİHADI IŞIĞINDA BİR INCELEME
}

\author{
Sanem BAYKAL ${ }^{*}$
}

\begin{abstract}
Özet
Avrupa Topluluğunun yarg1 organlarının münhasır yetkisine giren davalar arasinda yer alan iptal davası yoluyla hem Topluluk kurumlarının bağlayıcı tasarruflarının hukuka uygunluk denetimi gerçekleştirilmekte, hem de Topluluk hukukuna hakim olan ilkelerin Divan ve İlk Derece Mahkemesi tarafından yorumlanma ve geliştirilmesi imkanı doğmaktadır. Sınırlı yetki ilkesinin hakim olduğu Toplulukta, bu yetkinin sınırlarının ve çerçevesinin çizilmesi ve denetlenmesinde, dolayısıyla bir yandan üye devletlerle Topluluk, öte yandan da Topluluk kurumları arasındaki dengenin korunmasında iptal davası önemli bir rol oynamaktadır. Bundan başka, davanın ikinci bir temel fonksiyonu, bireysel hakların Topluluk düzeyinde etkili biçimde korunmasında oynadığı rolde kendisini göstermektedir. $\mathrm{Bu}$ çalışmada, konu ile ilgili Topluluk yargı organlarının içtihadı, son derece sınırlayıcı bir koşullar içeren özel kişilerin davacı olabilme koşulları perspektifinden incelenmektedir. Bu alandaki içtihadın bugüne kadarki gelişim çizgisi ortaya konarak, bundan sonra izleyebileceği yol eleştirel olarak ele alınmakta ve kurucu antlaşma değişikliğinin bu alanda gelişme kaydedilmesi bakımdan zorunlu hale geldiği ortaya konmaktadır.
\end{abstract}

\footnotetext{
* Yrd., Doç., Dr., Ankara Üniversitesi Hukuk Fakültesi, AB Hukuku Anabilim Dalı Öğretim Üyesi.
} 


\begin{abstract}
As a type of proceeding which is within the exclusive jurisdiction of the European Community courts, the action for annulment performs a dual function. Through this procedure the judicial review of Community acts is performed and the Community courts have the opportunity to construe and develop the general principles of Community law. Since the Community is founded on the principle of limited and attributed powers, the action for annulment has a significant role in delimiting and controlling the powers of the Community; by striking the institutional balance amongst the Community institutions on the one hand, and regulating the relations between those institutions and the Member States, on the other. Moreover, the action for annulment has another basic function, that is reflected in its role in the effective protection of individuals' rights at the Community level. This study focuses on the case-law of the Community courts in the field of action for annulment, with an emphasis on the rather strict conditions of private litigants' locus standi. The case-law is analysed with a view to make a prediction on its future line of development and as a conclusion it is argued that the treaty revision might have become the only way forward in this field.
\end{abstract}

\title{
Anahtar kelimeler
}

Avrupa Topluluğu Hukuku, Avrupa Toplulukları Adalet Divanı, AT'de Hukuka Uygunluk Denetimi, AT Hukukunda İptal Davası, Davacı Olma Koşulları

\section{Keywords}

European Community Law, European Court of Justice, Judicial Review in the EC, Action for Annulment in EC Law, Locus Standi

\section{Giriş}

Avrupa Birliği (AB) kurumlarının tasarruflarının hukuka uygunluk denetimi bakımından kurucu antlaşmalar esasen dört ayrı dava türü öngörmektedir. Bunlar Avrupa Topluluğunu kuran Antlaşmanın (AT Antlaşmas1) 230. maddesinde düzenlenen iptal davas1, 232. maddesinde düzenlenen hareketsizlik davas1, 288. maddesinin 2. paragrafinda düzenlenen tazminat davası ile 241. maddede düzenlenen hukuka aykırılık def'idir.

Topluluk yarg1 organları olarak isimlendirilebilecek olan Avrupa Toplulukları Adalet Divanı'nın (ATAD) ve İlk Derece Mahkemesi'nin (IDM) münhasır yetkisine giren bu davalar yoluyla Topluluk hukukunun tüm süjelerine $\mathrm{AB}$ kurumlarının hukuka aykırı işlemlerine karşı yargısal koruma sağlanmaktadır. Bunun yanı sıra, hukuka uygunluk denetimi yoluyla Birlik 
kurumlarının işlem ve eylemlerinin kurucu antlaşma tarafından belirlenen sınırlar içinde yapılmaları ve söz konusu kurumların Avrupa Birliğinde geçerli güçler dengesine uygun davranmaları da temin edilmektedir.

$\mathrm{Bu}$ davalar içinde Avrupa Birliği kurumlarının tasarruflarının hukuka uygunluk denetimi açısından en fazla öneme sahip bulunan iptal davası bu çalışmanın konusunu oluşturmaktadır. Demokratik, katılımcı, saydam, hesap verebilir, temel hakların güvence altına alındığı ve hukukun üstünlüğü ilkesinin geçerli olduğu siyasi yapılar bakımından bir yandan yasama tasarruflarının, öte yandan ise idarenin eylem ve işlemlerinin ${ }^{2}$ kapsayıcı ve etkili bir biçimde hukuka uygunluk denetimine tabi kılınması, sistemin hem hukuki ve hem de demokratik meşruiyetini temin etmenin koşullarından birini oluşturmaktadır. ${ }^{3}$ Elbette, Topluluk hukukunun kapsamına giren pek çok alanda olduğu üzere iptal davası alanında da Topluluk yargı organlarının içtihadı iptal davasına konu olabilecek tasarrufların nitelikleri, davacı ve davalı olabilme şartları, iptal nedenleri, iptal kararının hukuki sonuç ve etkileri gibi davanın unsurlarının belirlenmesi ve yorumlanmasında temel yol gösterici niteliğindedir. Ancak, söz konusu içtihat, iptal davasının, Topluluk hukukunun etkili biçimde uygulanması ${ }^{4}$ ve demokratik meşruiyetinin $^{5}$ güçlendirilmesi bakımından önemli bir işlevi yerine

1 P.S.R.F Mathijsen, A Guide to European Union Law, $6^{\text {th }}$ Edition, London, Sweet \& Maxwell, 1995, s. 89.

2 Topluluk hukukunun kendine özgü özellikleri nedeniyle iptal davasının konusunu hem yasama nitelikli işlemler, hem de idari tasarruflar oluşturmaktadır. Bkz. Albertina AlborsLlorens, Private Parties in European Community Law. Challenging Community Measures, Oxford, Clarendon Press, 1996, s. 7.

${ }^{3}$ Anthony Arnull, The European Union and Its Court of Justice, Oxford, New York, Oxford University Press, 1999, s. 47.

4 Topluluk hukukunun etkili biçimde uygulanması kavramı Divan tarafından tam olarak tanımlanmamış olmakla birlikte içtihadı en çok etkileyen kavramlardan birini oluşturmaktadır. Topluluk hukukunun etkili biçimde uygulanması konusunda $b k z$. Sanem Baykal, AT Hukukunun Etkili Biçimde Uygulanması ve Bireysel Haklar, Ankara, ATAUM Yayınları, No: 14, 2002; Josephine Steiner, Enforcing EC Law, London, Blackstone Press, 1995; Diedre Curtin, "Directives: The Effectiveness of Judicial Protection of Individual Rights", Common Market Law Review, Cilt 27, 1990, s. 709-739; Francis Snyder, "The Effectiveness of European Community Law: Institutions, Processes, Tools and Techniques", Modern Law Review, Cilt 53, 1993, s. 19-54.

${ }^{5}$ Avrupa Birliğinde demokratik meşruiyet sorunu hakkındaki son derece kapsamlı literatürden sınırlı bir seçki olarak bkz. Sanem Baykal, "Avrupa Birliğinin Geleceği: Meşruiyet Sorunu, Anayasalaşma Süreci ve Bütünleşmenin Nihai Hedefi Üzerine", Uluslararası İlişskiler, Cilt 1, No. 1, Bahar 2004, s. 119-153; Sinem Akgül Açıkmeşe, "Avrupa Birliğinde Demokratik Meşruiyet Sorunu", Ankara Avrupa Çalışmaları Dergisi, Cilt 2, Sayı 4, 2003, s. 23-45; Dieter Grimm, "Does Europe Need a Constitution?", European Law Journal, Cilt 1, 1995, s. 282302, J.H.H. Weiler-Ulrich R. Haltern-Franz C. Mayer, "European Democracy and Its Critique", West European Politics, Cilt 18, 1995, s. 4-39, J.H.H. Weiler, "Does Europe Need a Constitution? Demos, Telos and the German Maastricht Decision", European Law Journal, Cilt 1, 1995, s. 219-258, Aykut Çelebi, Avrupa: Halkların Siyasi Birliği, İstanbul, Metis, 2002; Erik Oddvar Eriksen ve John Erik Fossum (der.), Democracy in the European Union- 
getirdiğini göstermekle birlikte, Divanın pek çok başka alanda sergilediği aktivist tutumdan ${ }^{6}$ uzak, kurucu antlaşma maddelerinin metni ile sıkı sıkıya bağlı kalmayı tercih ettiği nadir alanlardan birini oluşturduğu izlenimini de doğurmaktadır. Özellikle özel kişilerin davacı olabilme koşulları bakımından karşımıza çıkan bu durumun değişmesi olasılığının son yıllarda belirmiş olmasına karşılık bu beklentinin gerçekleşmediğine tanık olmaktayız.

Bu çalışmada, Divanın ve Ilk Derece Mahkemesinin iptal davasina konu olabilecek tasarruflar ve iptal davasinda davacu olabilme koşulları ile ilgili içtihadını ele alacak; bu içtihadın özellikle bireylerin açtığ iptal davaları bakımından sinırlayıcı ve dar bir yoruma yer vermesinin ardinda yatan nedenleri araştıracağız. Bu çerçevede, öncelikle iptal davasina konu olabilecek tasarrufların nitelikleri ile davact ve davalı olabilme şartlarını, konu ile ilgili kurucu antlaşma değişiklikleri ve içtihat ışı̆̆ında başlangıçtan bugüne dek gelişimi bakımından ortaya koymaya çalışacağız. Ardından Divanın ve illk Derece Mahkemesinin iptal davasinın etkililiğini, özellikle özel kişilerin davacı olabilme koşulları alanındaki sınırlayıcı içtihadı yoluyla zayıflatmasinin ardinda yatan nedenleri ve bunlara karşı geliştirilen argümanları ele alacağız. Sonuç olarak, Avrupa Birliğinin bugün için içinde bulunduğu siyasi ve hukuki koşullar çerçevesinde bu alanda kurucu antlaşma değişikliği gerçekleşmediği sürece Topluluk yargl organlarından tutarlı ve kesin bir içtihat değişikliği beklemenin gerçekçi olmayacă̆ görüşünü ortaya koyacağız.

İptal Davasına Konu Olabilecek Topluluk Tasarrufları

AT Antlaşmasının 230. maddesinin özgün metninde iptal davasına konu olabilecek tasarruflar sınırlı şekilde ortaya koyulmuştur. Buna göre, sadece Bakanlar Konseyi ve Komisyonun tavsiye ve görüşler dışındaki tasarrufları hukuka uygunluk denetimine tabidir.

Integration Through Deliberation?, London- New York, Routledge, 2000.

${ }^{6}$ Divanın aktivist tutumu için bkz. Takis Tridimas, "The Court of Justice and Judicial Activism", European Law Review, Cilt 21, 1996, s. 199-223; Damien Chalmers, "Judicial Preferences and the Community Legal Order", Modern Law Review, Cilt 60, 1997; s. 164199; Trevor C. Hartley, "Five Forms of Uncertainty in European Community Law", Cambridge Law Journal, Cilt 55, 1996(a), s. 265-288; Trevor C. Hartley, "The European Court, Judicial Objectivity and the Constitution of the European Union", Law Quarterly Review, Cilt 112, 1996(b), s. 95-109; Rosa Diarmuid Phelan, Revolt and Revolution: The Constitutional Boundaries of the European Community, London, Sweet \& Maxwell, 1997; Hjalte Rasmussen, On Law and Policy in the European Court of Justice, Dordrecht, Martinus Nijhoff, 1986; David Edward, "Judicial Activism-Myth or Reality", David Campbell ve Meropi Voyatzi (der.) Legal Reasoning and Judicial Interpretation of European Law, Essays in Honour of Lord MacKenzie Stuart, Hampshire, Trenton Publishing, 1996, içinde, s. 29-67; Anthony Arnull, "The European Court and Judicial Objectivity: A Reply to Professor Hartley”, Law Quarterly Review, Cilt 112, 1996, s. 411-423. 
Buna karşılık, Adalet Divanı, çeşitli kararlarında bu kategoriye giren tasarrufların sayısını genişletici yönde yorumda bulunmuştur. Divana göre, AT Antlaşması 249. maddede Topluluk organlarının tasarrufları sayılmakta ve bunlardan tavsiye ve görüşler dışındaki diğer üçünün bağlayıcı nitelikte olduğu belirtilmektedir. ${ }^{7} 230$. madde metninde sayılan ve iptal davasına konu olamayacak tasarruf türlerinin ortak özelliği bağlayıcı etki doğurmamaları olduğuna göre, madde, hukuken bağlayıcı olan tüm Topluluk tasarruflarının hukuka uygunluk denetimine tabi olacağ 1 şeklinde yorumlanmalıdır. Divan burada sadece 249. maddede sayılan bağlayıcı tasarrufların değil, kurucu antlaşmalarda öngörülen veya uygulamada Topluluk organları tarafindan başvurulan her türlü bağlayıcı tasarrufun da 230. madde kapsamına gireceğine hükmetmiştir. ${ }^{8}$ Böylece, Divan, hukuka uygunluk denetimine tabi tasarruflar konusunda oldukça genişletici bir yorumu benimsemiştir.

Yukarıdaki saptamanın yapıldı $\breve{g} 1$ ve atıfta bulunulan E.R.T.A davasında sorun, Konsey ve Komisyonun hukuki etkiler doğurmakla birlikte, 249. madde metninde sayılan bağlayıcı tasarruflar arasında yer almayan tasarruflarına karșı iptal davası açılıp açılamayacağı şeklinde ortaya çıkmıştır. Divan, 230. maddenin hukuki etki doğuran tüm Topluluk tasarruflarına karşı dava açılmasını öngördügünü belirtmiştir. Divan’a göre, iptal davasının amacı 220. madde ${ }^{9}$ ile birlikte Antlaşmanın uygulanması ve yorumunda hukuka saygının teminidir. Divan, davanın kabul edilebilirliği ile ilgili koşulların daraltıcı yoruma tabi tutulmasının bu amaçla bağdaşmayacağını vurgulamıştır. ${ }^{10}$

Divan içtihadı uyarınca, tasarrufun şekli ve adı, ilke olarak, aleyhine iptal davası açılıp açılmaması konusunda belirleyici değildir. ${ }^{11}$ Bunun yerine tasarrufun içeriğine ve niteliğine bakılmalıdır. Gerçekten de, 230. madde kapsamındaki tasarrufların temel özellikleri bağlayıcı olmalarıdır. Bağlayıcı olmanın anlamı ise, hukuki sonuç doğurma; kișilerin hukuki durumu üzerinde değişiklik meydana getirmedir. Bir kişinin hukuki durumu hak ve borçlarının bütününü ifade ettiğinden bağlayıcı bir Topluluk tasarrufunun kişilerin hak ve borçları üzerinde değişiklik getirmesi gerekmektedir. ${ }^{12}$

\footnotetext{
${ }^{7}$ AT Antlaşmasının 249. maddesinde düzenlenen bağlayıcı tasarruf türleri tüzükler, direktifler ve kararlar olarak karşımıza çıkmaktadır.

${ }^{8}$ 22/70, Commission v. Council (ERTA Case), [1971] ECR 263.

${ }^{9}$ Nice Antlaşması ile değişik AT Antlaşması 220. maddenin 1. paragrafı uyarınca: “Avrupa Toplulukları Adalet Divanı ve İlk Derece Mahkemesi, her biri kendi yetkileri dahilinde, bu Antlaşmanın yorumu ve uygulanmasında hukuka saygıyı sağlar."

${ }^{10}$ Anthony Arnull, "Private Applicants and the Action for Annulment under Article 173 of the EC Treaty", Common Market Law Review, Cilt 32, 1995, s. 17.

${ }^{11}$ Mathijsen, op.cit., s. 90.

12 T.C. Hartley, The Foundations of European Community Law, $5^{\text {th }}$ Edition, Oxford-New York, Oxford University Press, 2003, s. 338-340.
} 
Divan, iptal davasına konu olabilecek tasarrufların hukuken bağlayıcı nitelikte olmaları gerektiği genel ilkesini ortaya koyduktan sonra verdiği çeşitli kararlarla konu ile ilgili içtihadını geliştirme imkanını bulmuştur.

Divanın bu çerçevede çözüm aradığı sorunlardan biri, bir kararın alınması için uygulanması gereken prosedürün, her biri birer hazırlık aşaması ya da ön karar olarak kabul edilebilecek çok sayıda aşamadan oluşması durumudur. Örneğin, nihai karar alınmadan çeşitli kurumların görüşlerinin alınması gerekebilir. Bu görüşlerin alınması gerekmekle birlikte bunlara uyulması konusunda bir zorunluluk bulunmuyorsa, söz konusu görüşün bağlayıcı olmaması sebebiyle 230. madde kapsamında iptal davasına konu olamayacağı sonucuna varılabilir. Buna karşılık, görüş bağlayıcıysa, yani kararın alınabilmesi için görüşün olumlu olması gerekiyorsa, bu hazırlık işlemi nihai kararı alacak olan organın takdir yetkisini etkilemektedir ve bu nedenle bağlayıcı nitelikte kabul edilebilir. ${ }^{13}$

Ancak, Divan bu yaklaşımı benimsememiştir. Örneğin, Huber v. Commission kararında Divan, bir Topluluk görevlisinin işe alınmasını "Yerleştirme Komitesinin" olumlu görüşüne bağlayan Personel Tüzüğünün ilgili maddesi karșısında bu Komitenin kararının 230. madde kapsamında denetime tabi bir tasarruf sayılmasını, nihai kararla ayrılmaz bir bütün oluşturduğu gerekçesiyle reddetmiştir. ${ }^{14}$ Divanın bu kararı sonucunda, bu tarz hazırlık aşaması kararlarının, ilgili kişinin hukuki durumunu nihai karardan bağımsız olarak etkilememesi halinde kendi başlarına iptal davasına konu olamayacakları açıktır.

Buna karşı1ık, Noordwijks davasında Divan, Topluluk Rekabet Hukukunun uygulanmasından doğan bir cezadan muafiyetin kaldırıldığ 1 yönündeki Komisyon bildirimini 230. madde kapsamında bağlayıcı bir Topluluk tasarrufu olarak kabul etmiştir. ${ }^{15}$

$I B M$ v. Commission kararında ise Divan, Komisyonun, firmaya kendisi hakkında 17/62 sayılı Tüzük uyarınca rekabete aykırı davranışları ile ilgili olarak soruşturma başlatıldığını ve belli sürede cevap vermesini bildiren mektubunun 230. madde kapsamında olmadığına karar vermiştir. ${ }^{16}$ Divana göre, nihai bir kararı hazırlamaya yönelik geçici tedbir ve tasarruflar 230. madde kapsamında bağlayıcı tasarruf teşkil etmezler. Buna karşılık, Divan, bir başka kararında Komisyonun rekabet hukuku gibi şikayet üzerine soruşturma ve para cezası verme yetkisine sahip olduğu bir alanda, konuyu soruşturmayacağını açıklayan mektubunun hukuki sonuçlar doğuran, hukuka uygunluk denetimine tabi bir işlem oluşturacağına hükmetmiştir. ${ }^{17}$ Benzer

${ }^{13}$ Ibid., s. 340-347.

${ }^{14}$ 78/63, Huber v. Commission, [1964] ECR 367.

15 8-11/66, Cimenteries v. Commission, [1967] ECR 75.

${ }^{16} 60 / 81$, IBM v. Commission, [1981] ECR 2639.

${ }^{17}$ C-39/93P, Syndicat Français de l'Express International (SFEI) v. Commission, [1994] ECR I-2681. 
şekilde, örneğin $A K Z O$ Chemie v. Commission davasında olduğu gibi gizli belgelerin açıklanmasına yönelik bir hazırlık aşaması kararı bu çerçevede değerlendirilemeyecektir. ${ }^{18} \mathrm{Bu}$ tarz bir karar, ilgilinin hukuki durumu üzerinde bağlayıcı ve telafi edilemez etkiler doğurma niteliğine sahip olduğundan 230. madde uyarınca iptali istenebilecektir. Nihai kararın iptali, firmanın Komisyon tarafından alınan, gizli belgelerin açıklanması kararının sonucunda uğrayacağı zararı yeterince telafi etmekten uzaktır ve bu nedenle söz konusu karar sadece bir hazırlık aşaması kararı olarak nitelendirilemez. ${ }^{19}$

Divan kararları ile ortaya konan bir başka ilke ise, bir tasarrufun sadece daha önceki bir tasarrufu teyit etmeye yönelik nitelikte olması durumunda hukuki etki doğurmayacağıdır. Ancak, ilk tasarrufun kabulünden sonra koşullarda temelli bir değişiklik meydana gelmişse durum farklı olacaktır.

Buna karş1lık, bir Topluluk kurumu ileride nasıl hareket edeceğini belirleyen ve bu açıdan kendisini bağlayan bir tasarrufta bulunursa, bu tasarruf da bağlayıcı nitelikte kabul edilir. Böyle bir durumda tasarruf, özellikle farklı bir tutum benimsenmiş olsaydı bundan menfaat elde edeceklerin hukuki durumunu etkilemektedir. ${ }^{20}$ İlgili kurum bu tasarrufunu geri alabilir, ancak geri alana dek tasarrufla bağlı ise bunun hukuki denetime tabi bir tasarruf olduğunun kabul edilmesi gerekir. ${ }^{21}$

Öte yandan, bir Topluluk kurumunun belli şartlar altında benimseyeceği hareket tarzı konusunda niyetini beyan etmesi halinde bu beyan kesin ve şartsız ise 230. madde kapsamında iptal edilebilir bir hukuki tasarruf sayılacaktır. ${ }^{22} \mathrm{Bu}$ durumda ilgili kurumun bu tarz bir beyanla hukuken bağlı olup olmaması önem taşımayacaktır.

Üye devletlerin temsilcileri tarafindan, üye devlet sifat ve yetkilerini kullanarak topluca alınan kararlar iptal davasına konu değildir. ${ }^{23}$ Çünkü böyle bir durumda karar, "Konsey" sıfatıyla değil, üye devlet temsilcileri sıfatı ile alınmaktadır. Buna karşılık Konsey, AT Antlaşmasının kapsamı dışında kaldığı ${ }^{24}$ ve AB Antlaşmasının kapsamına girdiğ $i^{25}$ kanısıyla bir karar alırsa, Divan, söz konusu kararın AT Antlaşması kapsamına ve dolayısıyla kendisinin hukuka uygunluk incelemesine konu olup olamayacağını araştırma yetkisi bulunduğuna hükmetmiştir. ${ }^{26}$

${ }^{18}$ 53/85, AKZO Chemie v. Commission, [1986] ECR 1965.

${ }^{19}$ Stephen Weatherill ve Paul Beaumont, EU Law, ${ }^{\text {rd }}$ Edition, London, Penguin Books, 1999, s. $249-250$.

${ }^{20}$ Hartley, op.cit., 2003, s. 344.

${ }^{21}$ 15/63, Lasalle v. European Parliament, [1964] ECR 31.

22 8/55, Fédération Charbonnièr de Belgique v. High Authority, [1956] ECR 245.

${ }^{23}$ C-181 ve 248/91, European Parliament v. Council and Commission, [1993] ECR I-3685. Bkz. Paul Craig and Gráinne de Búrca, EU Law. Text, Cases and Materials, $3^{\text {rd }}$ Edition, Oxford-New York, Oxford University Press, 2003, s. 485.

${ }^{24}$ C-316/91, European Parliament v. Council, [1994] ECR I-625.

${ }^{25}$ C-170/96, Commission v. Council, [1998] ECR I-2763.

${ }^{26}$ Weatherill ve Beaumont, op.cit., s. 246. 
230. maddenin özgün metninde sadece Konsey ve Komisyon tasarruflarının iptal edilebileceğinden bahsedilse de, Divan Les Verts davasında verdiği kararla bu kapsama belli şartları taşıyan Avrupa Parlamentosu tasarruflarını da dahil etmiştir. ${ }^{27}$

İlgili davada iki Fransız siyasi partisi Avrupa Parlamentosu tarafindan seçim kampanyalarının finansmanına dair kabul edilen iki tasarrufun iptalini talep etmiştir. Davanın açıldığı sırada Parlamento 230. madde metninde tasarrufları aleyhine iptal davası açılabilecek kurumlar arasında sayılmadığı gibi, tüzük, direktif, karar gibi bağlayıcı tasarrufların çıkartılmasına katkıda bulunma imkanı da sadece danışma usulü ile sınırlı bulunmaktaydı. Buna karş1lık Divan, Parlamentonun üçüncü kişilerin hukuki durumu üzerinde etkiler doğuran tasarruflarının 230. maddede öngörülen hukuki denetimin dışında bırakılmasının kurucu antlaşmanın ruhu ile bağdaşmayacağı yolunda yorumda bulunmuştur. ${ }^{28}$

Nitekim, Divanın bu içtihadı kurucu antlaşmalara değişiklik getiren Maastricht Antlaşmasının ilgili hükmü ile de teyit edilmiş ve Avrupa Parlamentosunun bazı tasarruflarının iptal davasına konu olabileceği AT Antlaşmasına geçirilmiştir. ${ }^{29}$ Parlamentonun konumunun ve yetkilerinin ve kurumsal yapıdaki dengelerin geçirdiği köklü değişimi ve gelişimi yansıtan bu Divan kararı sonucu, AT Antlaşmasının Parlamento tasarruflarının iptal davasına konu olabilmesine ilişkin hükmü çerçevesinde Parlamento ve Konseyin ortak karar usulü ${ }^{30}$ uyarınca ortaklaşa karara bağladıkları tasarrufların yanı sıra, Parlamentonun üçüncü kişilerin hukuki statüleri üzerinde etki doğuran tasarruflarının da iptal davasına konu olabilecekleri öngörülmektedir. ${ }^{31}$ Buna göre, örneğin Parlamento Başkanının Birlik bütçesinin nihai olarak kabul edildiği yönündeki beyanı ${ }^{32} 230$. madde uyarınca iptal edilebilir bir tasarruf olarak kabul edilebilecek, ancak yine Parlamentonun soruşturma komisyonu kurmaya yönelik kararr ${ }^{33}$ üçüncü kișiler üzerinde hukuki etkiler doğurmadığı gerekçesiyle iptal davasına konu olamayacaktır. ${ }^{34}$

${ }^{27}$ 294/83, Les Verts v. European Parliament, [1986] ECR 1339.

${ }^{28}$ Arnull, op.cit., 1995, s. 17.

${ }^{29}$ Maastricht Antlaşması ile 230. maddeye getirilen değişikliğe göre, Avrupa Parlamentosu ile Konseyin ortak karar usulü uyarınca aldığı kararlar ile Avrupa Parlamentosunun üçüncü kişiler için önemli etkiler doğurmaya yönelik tasarrufları Divanın hukuka uygunluk denetimi kapsamına alınmıştır.

${ }^{30} \mathrm{Bkz}$. AT Antlaşması madde 251.

${ }^{31}$ Parlamento ve Konseyin ortak karar usulüne göre karara bağladıkları ve iptal edilen ilk Topluluk direktifini konu alan ve tütün reklamlarının düzenlenmesi ile ilgili ünlü Divan kararı için bkz. C-376/98, Germany v. Parliament and Council (Tobacco Advertising Case), [2000] ECR I-8419.

32 34/86, Council v. European Parliament, [1986] ECR 2155.

${ }^{33}$ 75/85, Group of the European Right v. European Parliament, [1986] ECR 1753.

${ }^{34}$ Weatherill ve Beaumont, op.cit., s. 252. 
Nice Antlaşması sonucu da değişmeyen bu hüküm uyarınca bugün için iptal davasına konu olabilen tasarruflar 230. maddenin 1. paragrafinda şu şekilde düzenlenmektedir: "Adalet Divan1, Avrupa Parlamentosu ile Konsey'in ortaklaşa, Konsey'in, Komisyon'un ve Avrupa Merkez Bankası'nın tavsiyeleri ile görüşleri dışında kalan tasarrufları ile Avrupa Parlamentosu'nun üçüncü şahıslar nezdinde hukuki etki doğuran tasarruflarının hukuka uygunluğunu denetler."

Bir Topluluk kurumunun yetkilerini bir başka makama devretmesi halinde bu makamın bağlayıcı tasarruflarının iptal davasına konu olup olamayacağı da yine Divan içtihadı ile çözüme kavuşturulmuş bir konudur. Buna göre, yetkinin devredildiği kurumun da Topluluk organı olması halinde mesele yoktur. Ancak, yetki, Topluluk kurumu adına hareket eden bir başka makama devrediliyorsa genel kural, kararlarına karşı iptal davası açılabilen bir Topluluk kurumunun devrettiği bu yetkileri kullanarak tasarrufta bulunan makamın aldı̆̆ kararların da 230. madde çerçevesinde hukuken denetlenebileceğidir. ${ }^{35}$ Konu ile ilgili SNUPAT v. High Authority kararında Divan, Yüksek Otorite tarafından Belçika mevzuatına göre kurulmuş hurda çelik kooperatiflerinin aldıkları kararların hem kuruluș biçim ve yöntemleri, hem de kararlarının nihai sayılması nedeniyle iptal davasına konu olabileceğine hükmetmiştir. ${ }^{36}$

Üçüncü sütun çerçevesinde hukuka uygunluk denetimi bakımından iptal davası, yalnızca "çerçeve karar" ve "karar"lara karşı açılabilecektir. Dolayısıyla sözleşmeler ve sözleşmelerin uygulama önlemleri, iptal davasının kapsamı dışında bırakılmıştır. ${ }^{37}$ Divan, ayrıca, AT sütununda karara bağlanmış olması gerektiği halde $\mathrm{AB}$ Antlaşması çerçevesinde karar bağlandığ 1 ileri sürülen tasarrufları da iptal davası kapsamında denetlemektedir. ${ }^{38}$

İptal Davası ve Davacı Olma Koşulları

\section{A. Üye Devletler ve Topluluk Kurumları (İmtiyazlı ve Yarı İmtiyazlı Davacılar) Bakımından}

230. madde uyarınca iptal davası açmak isteyen ilgilinin, madde metninde sayılan davacı olmaya ilişkin koşulları yerine getirmesi gereklidir.

\footnotetext{
${ }^{35}$ Hartley, op.cit., 2003, s. 346-347.

36 32-33/58, SNUPAT v. High Authority, [1959] ECR 127.

${ }^{37} \mathrm{Bkz}$. AB Antlaşması madde 35.

${ }^{38}$ C-170/96, Commission v. Council (Airport Transit Visas), [1998] ECR I-2763. Üçüncü sütunda iptal davası hakkında bilgi için $b k z$. Dierdre Curtin ve Ige Dekker, "The EU as a 'Layered' International Organization: Institutional Unity in Disguise”, Paul Craig and Gráinne de Búrca (der.), The Evolution of EU Law, Oxford-New York, Oxford University Press, 1999, içinde, s. 122-124.
} 
Bu açıdan 230. madde Avrupa Birliğinin kurumları ve üye devletler ile özel kişiler arasında bir ayrıma gitmektedir. İlk kategoriye giren davacıların da kendi içinde ikiye ayrılması mümkündür. Nice Antlaşması ile değişik 230. maddenin 2. paragrafi uyarınca Konsey, Komisyon, Avrupa Parlamentosu ve üye devletlerin dava açabilmeleri için herhangi bir ilgi veya menfaat ispat etmeleri gerekmez. ${ }^{39} \mathrm{Bu}$ gruba giren davaciların, Topluluk tasarruflarının hukuka uygunluğunun temininde genel olarak menfaatleri bulunduğu kabul edilmektedir. ${ }^{40} \mathrm{Bu}$ nedenle de literatürde sik sik imtiyazlı davacilar olarak adlandırıldıkları görülmektedir. Hatta bir üye devlet Konseyde karara bağlanmış bir tasarrufun iptalini, oylama sırasında lehte ya da aleyhte oy kullanmış olmasına bakılmaksızın Divandan talep edebilmektedir. ${ }^{41}$

Buna karşı1ık, Avrupa Sayıştayı ve Avrupa Merkez Bankası, kendi yetkilerini koruma amacıyla sınırlı olarak iptal davası açma yetkisine sahip kılınmış, "yarı imtiyazlı" olarak kabul edilen davacı kategorisini oluşturmaktadır.

Maastricht ve Nice Antlaşmaları ile getirilen değişikliklerin öncesinde kurucu antlaşmanın özgün metninde öngörülmemiş olmakla birlikte Avrupa Parlamentosunun iptal davası açabilme yetkisi Divan tarafından hükme bağlanmıştır. Konu ile ilgili ilk içtihadında Divan, Parlamentonun 230. maddede öngörülen aktif ve pasif rollerinin denge içinde bulunduğu gerekçesiyle bu kurumun açtığı iptal davasını reddetmiştir. ${ }^{42}$ Divana göre, Parlamento 230. maddenin özgün metni uyarınca davalı olamadığına göre davacı da olamaz. Konseyin Parlamentonun yetkilerine saygı göstermemesi durumunda buna engel olacak ve dava açacak kurum Komisyondur.

Ancak, Divan, bu içtihadını kısa bir süre sonra değiştirmiş ve Avrupa Tek Senedi ile yeni yetkiler kazanan Avrupa Parlamentosuna davac1 olabilme imkanını tanımıştır. Konu ile ilgili davada Divan, Parlamentonun kurucu antlaşmalardan kaynaklanan yetkilerini korumak amacıyla sınırlı olmak üzere iptal davası açabileceğine hükmetmiş, Avrupa Parlamentosuna yarı imtiyazlı davacı statüsü tanımıştır. ${ }^{43}$ Maastricht Antlaşması ile Divanın

\footnotetext{
39 45/86, Commission v. Council, [1987] ECR 1493.

${ }^{40}$ Derrick Wyatt ve Alan Dashwood, Wyatt and Dashwood's European Community Law, $3^{\text {rd }}$ Edition, London, Sweet \& Maxwell, 1993, s. 122.

${ }^{41}$ 166/78, Italy v. Council, [1979] ECR 2575.

42 302/87, European Parliament v. Council (Comitology), [1988] ECR 5615.

${ }^{43}$ C-70/88, European Parliament v. Council (Chernobyl), [1990] ECR I-2041. Bkz. Gerhard Bebr, "The Standing of The European Parliament in the Community System of Legal Remedies: A Thorny Jurisprudential Development", Yearbook of European Law, Cilt 10, 1990, s. 170. Genel olarak Avrupa Parlamentosunun yetkilerinin artışında Divanın rolü ve kurumsal dengeye katkısı hakkında $b k z$. Harm Schepel ve Erhard Blankenburg, "Mobilizing the European Court of Justice", Gráinne de Búrca ve J.H.H. Weiler (der.) The European Court of Justice, The Collected Courses of the Academy of European Law, EUI, Oxford-New York, Oxford University Press, 2001, içinde, s. 18-21.
} 
bu içtihadı kurucu antlaşmaya geçirilerek Parlamentoya ve Avrupa Merkez Bankasına kendi yetkilerini koruma amacıyla sınırlı olarak davacı olabilme imkanı tanınmıştır.

Divanın bu tarz bir içtihat değişikliğini tercih etmesinin ardında yatan neden, Avrupa Parlamentosunun karar alma süreçlerinde ve kurumsal dengede gittikçe güçlenen konumunun Divan içtihadına da yansıtılması gereği olarak açıklanabilir. Ancak, dikkat edilmesi gereken husus, kurucu antlaşmanın metni açıkça böyle bir içtihada imkan tanımadığı halde Divanın, Parlamentonun davaci olabilmesi lehinde bir yorumu Avrupa bütünleşmesinin amaçları bakımından zorunlu görmesi sonucu benimsemekte çok da büyük tereddüt göstermemesidir. Oysa, aşağıda görüleceği üzere, Divan, özel kişilerin iptal davası açabilmelerine ilișkin kurucu antlaşma hükmünü harfiyen uygulamayı tercih etmekte; burada amaçsal yorum yöntemine başvurmamaktadır.

Yukarıda da belirtildiği üzere, Nice Antlaşması ile getirilen değişiklik uyarınca artık Parlamento aynen Konsey, Komisyon ve üye devletler gibi herhangi bir kısıtlamaya tabi olmaksızın iptal davası açabilecek davacılar kategorisine dahil edilirken, Avrupa Sayıştayı ${ }^{44}$ ve Avrupa Merkez Bankası bugünkü durumda kurucu antlaşmadan kaynaklanan yetkilerini koruma amacıyla sınırlı olarak iptal davası açabileceklerdir. ${ }^{45}$

Üçüncü sütun çerçevesinde ise iptal davasını açmaya sadece Komisyon ve üye devletler yetkilidir. 35. maddenin 6. paragrafı, iptal davası açmaya yetkili organlar arasında Avrupa Parlamentosunu saymamıştır. Oysa Tezcan tarafindan da belirtildiği üzere, 39. maddeye göre, bu alanda Avrupa Parlamentosunun danışma yetkisi söz konusudur ve bu yetkinin Konsey tarafindan ihlali nedeniyle Parlamentoya iptal davası açabilme yetkisi doğması gerekir; dolayısıyla Adalet Divanının, 35. maddenin 6 . paragrafındaki bu boşluğu, AT Antlaşması çerçevesindeki içtihadına paralel yönde izleyeceği bir içtihatla doldurması beklenebilir. ${ }^{46}$

\section{Özel Kişiler (İmtiyazlı Olmayan Davacılar) Bakımından}

Gerçek ve tüzel kişilerin iptal davası açabilmeleri Topluluk hukukunda oldukça sınırlı şartlarla kabul edilmiştir. 230. maddenin 4. paragrafına göre bu kategoriye giren davacilar:

- Kendilerini muhatap alan kararlara karşı,

\footnotetext{
44 Avrupa Sayıştayına yarı imtiyazlı davacı olma statüsü Amsterdam Antlaşması değişiklikleriyle tanınmıştır.

${ }^{45} \mathrm{Bkz}$. AT Antlaşması madde 230 paragraf 2 ve 3.

${ }^{46}$ Ercüment Tezcan, Avrupa Birliği Hukukunda Birey, İstanbul, İletişim, 2002, s. 329-330.
} 
- Başkasını muhatap almakla birlikte kendilerini doğrudan ve bireysel olarak ilgilendiren kararlara karşı,

- Kendilerini doğrudan ve bireysel olarak ilgilendiren tüzük görünümündeki kararlara karş1

iptal davası açabilirler.

230. maddenin 4. paragrafi özel kişilerin direktiflerin iptali için dava açabilmesi konusunda herhangi bir hüküm içermemektedir. Bununla birlikte, direktiflerin üye devletlere yönelik karar niteliği taşıdıklarına göre kişileri doğrudan ve bireysel olarak etkiledikleri ölçüde aleyhlerine iptal davasi açılabileceği yönünde görüşlere doktrinde rastlanmaktadır. ${ }^{47}$

Ancak, Divan tarafından benimsenen hakim görüşe göre gerçek anlamda direktiflere karşı özel kişilerce iptal davası açılabilmesi bunların genel düzenleyici işlem niteliğini haiz olmaları nedeniyle mümkün değildir. ${ }^{48}$ Direktifler, sadece içerik itibariyle karar niteliğinde olduklarının ispatı halinde özel kişiler tarafından açılacak iptal davalarına konu olabilecektir. ${ }^{49}$ İlk Derece Mahkemesi, UEAPME v. Council kararında bir tasarrufun direktif olarak nitelendirilmesinin, tek başına, bireylerin iptal davası açma imkanlarını ortaya kaldıramayacağını ve Topluluk kurumlarının bir hukuki tasarruf aracı seçme yoluyla bireyleri kurucu antlaşma hükümlerinden kaynaklanan etkili korunma imkanlarından mahrum bırakamayacağını vurgulamaktadır. ${ }^{50}$

Açıkça davacıyı muhatap alan bir kararın iptali için başvurulması halinde, dava açma hakkının bulunduğu yönünde bir karine mevcuttur. Dolayısıyla muhatabı olunan kararlara karşı dava açılması halinde münhasır bir ilgi veya menfaat ispatına gerek bulunmamaktadır. ${ }^{51}$

Tüzüklere veya muhatabı olunmayan kararlara karşı dava açılması durumunda ise 230. madde, davacıların söz konusu tasarrufun tüzük görünümünde olmasına karşılık gerçekte karar niteliğinde olduğunu ve kendilerini doğrudan ve bireysel olarak ilgilendirdiğini ispat etmelerini şart koşmaktadır.

$\mathrm{Bu}$ üç koşulun birlikte mi, ayrı ayrı mı ele alınması gerektiği konusunda Divan kesin bir tutum benimsememiştir. ${ }^{52}$ Gerçekten de Divanın özel kişilerin iptal davası açabilmeleri konusundaki içtihadı, bazı davalarda esnek bir yaklaşımı ortaya koymakla birlikte, genel olarak sınırlayıcı olup, istikrarlı

\footnotetext{
${ }^{47}$ Wyatt ve Dashwood, op.cit., s. 173.

${ }^{48}$ C-298/89, Gibraltar v. Council, [1993] ECR I-3605.

${ }^{49}$ Craig ve de Búrca, op.cit., s. 487-488.

${ }^{50}$ T-135/96, UEAPME v. Council, [1998] ECR II-2335.

${ }^{51}$ Hartley, op.cit., 2003, s. 358.

${ }^{52}$ Weatherill-Beaumont, op.cit., s. 254-255.
} 
bir otorite oluşturmaktan uzaktır. ${ }^{53}$ Esasen imtiyazlı olmayan kişilerin iptal davaları açabilmeleri bakımından sorun bireysel ilginin varlığı ile davacı olma, kararın alınmasına katılım ve müdahale yetkisi arasındaki ilişki üzerinde yoğunlaşmaktadır. ${ }^{54}$

Divan, konu ile ilgili ilk kararlarında bir tasarrufun tüzük mü, karar mı olduğunu belirlemede bu düzenlemeden bireysel olarak etkilenenler olup olmadığına bakılmasının gerektiğini belirtmiştir. ${ }^{55}$ Ancak, daha sonra bu yöndeki içtihadını değiştiren Divan, bu iki farklı kriterin bir arada yerine gelmesini davacılık sıfatının gerçekleşmesi bakımından zorunlu saymıştır. ${ }^{56}$ Aşağıda öncelikle Divanın bir tasarrufun tüzük mü, karar mı olduğunu belirlemede kullandığ 1 kıstasları ele alacağız.

\section{Tüzük-Karar Ayrımı}

$\mathrm{Bu}$ ayrım daha çok tasarrufun ne şekilde adlandırıldığ 1 ile ilgilidir. Divan, 230. maddenin 4. paragrafının amacının Topluluk organlarının tüzük biçiminde bir işlem yapma yoluyla kişilerin kendilerini doğrudan ve bireysel olarak ilgilendiren tasarruflara karşı dava açma imkanlarını ellerinden almalarını engellemek olduğunu belirtmektedir. ${ }^{57}$ Ancak, bu görüş sadece Antlaşmanın kullanılması gereken tasarruf türünü açıkça belirtmediği hallerde geçerli olabilir. ${ }^{58}$ Eğer bir tasarrufun hukuki dayanağı sadece tüzük biçiminde bir işlem yapılmasını öngörüyorsa ve davacı da 230. madde çerçevesinde açtığ $\breve{l}_{1}$ davada bu işlemin aslında karar niteliğinde olduğunu ispat ederse, söz konusu işlemin geçersiz olduğuna karar verilmelidir; çünkü davalı Topluluk kurumunun ilgili konuda karar alma yetkisi bulunmamaktadır.

Bunun da ötesinde, kararların yürürlüğe girebilmeleri için muhataplarına bildirim yapılması gereklidir. Tüzükler genel ve doğrudan uygulanır işlemler olduklarından belirli muhatapları olmadığı gibi, herhangi bir kimseye bildirilmeleri de gerekmez. Dolayısıyla, davacının tüzük görünümündeki bir tasarrufun gerçekte karar niteliğinde olduğunu ispat etmesi halinde bu tasarrufun aslında başından beri hukuki etki doğurmadığı da ortaya konmuş olmaktadır; tasarruf muhatabına bildirilmediğinden yürürlüğe de girmemiştir. ${ }^{59}$

\footnotetext{
${ }^{53}$ Lasok ve Bridge, Law and Institutions of the European Communities, $5^{\text {th }}$ Edition, London, Butterworths, 1991, s. 301.

${ }_{55}^{54}$ Craig ve de Búrca, op.cit., s. 515-518.

55 16-17/62, Confédération nationale de producteurs de fruits et légumes v. Council, [1962] ECR 471.

${ }^{56}$ Hartley, op.cit., 2003, s. 361-362.

${ }^{57}$ 162/78, Wagner v. Commission, [1979] ECR 3467.

${ }^{58}$ Arnull, op.cit., 1995, s. 15.

${ }^{59}$ Ibid., s. 15.
} 
Buna karşılık, yukarıdaki mülahazalar, davacının dava açma yetkisinin bulunduğunu, yani tüzük görünümündeki bir tasarrufun aslında karar olduğunu ispat etmesinin tek başına tasarrufun iptaline yol açacağı anlamına gelmemektedir. Davacılık sıfatını ispatlayan ilgili, tasarrufun iptali için aynı zamanda Antlaşmada sayılan dört iptal nedeninden birinin mevcudiyetini de ispatlamak durumundadir. ${ }^{60}$

Özel kişilerin iptal davası açabilmeleri konusunda tasarrufun adından çok niteliği ve içeriği önemlidir. 230. madde metninde yer alan "tüzük şeklinde olmakla birlikte" cümlesi de bu kanıyı güçlendirmektedir. Divanın bu konudaki içtihadının altında da bu görüş yatmaktadır. Divan bir tasarrufun tüzük mü, karar mı olduğu saptarken kendisini tasarrufun resmi adı ile sınırlamayacağını, öncelikle tasarrufun amaç ve içeriğini göz önüne alacağını belirtmektedir. ${ }^{61}$

Divan, 230. maddeden hareketle tüzük ile karar arasındaki belirleyici farkın ilgili tasarrufun genel biçimde uygulanması olduğunu vurgulamıştır. Buna göre, tüzükler temel yasama işlemi karakterli olup, soyut ve genel biçimde belirlenen kategorilere uygulanırlar. Kararların uygulanırlığı ise daha spesifiktir. Kararlar muhatap aldıkları kișilerin sınırlı sayıda olması ile tüzüklerden ayrılırlar. Tasarruf belirli kişileri ilgilendiriyorsa karar niteliğindedir. $\mathrm{Bu}$ ayrımın en önemli noktası tasarruftan etkilenmek ile onunla bağlı olmak arasındaki fark olarak ortaya çıkmaktadır. ${ }^{62}$ Gerçek anlamda bir karar sadece belli bir kategoriye girenleri bağlarken, gerçek bir tüzük potansiyel olarak herkesi bağlar; ancak bundan etkilenenlerin sayıs1 sinırlı olabilir.

Yine de böyle bir ayrıma gitmenin, özellikle belli bir kategoriye giren kişilerin sayısının az olması ve etkilenen kişilerin genel bir kategoriye girmekle birlikte kimliklerinin tasarrufun yapıldığ 1 sirada belirli veya belirlenebilir olması durumlarında son derece güç olduğu da açıktır. ${ }^{63}$

\footnotetext{
${ }^{60}$ İptal nedenleri kurucu antlaşmada sınırlı biçimde sayılmıştır. Bir Topluluk tasarrufu ancak Antlaşmada sayılmış bulunan bu nedenlere dayanılarak hukuka uygunluk incelemesine tabi tutulur. Söz konusu nedenler şunlardır: 1. Yetkisizlik, 2. Esaslı şekil sakatlığı, 3. Kurucu Antlaşmanın veya onun uygulanmasına ilişkin bir kuralın ihlali ve 4. Yetki saptırması ya da yetkinin kötüye kullanılması. Bkz. AT Antlaşması madde 230. paragraf 2. Bu konuda genel olarak bkz. Ali Ülkü Azrak, Avrupa Topluluklarında İdari Yargının Genel Esasları, İstanbul, İ.Ü. S.B. F Yayınları No. 8, 1982, s. 119-126; Tuğrul Arat, Avrupa Toplulukları Adalet Divanı, Ankara, ATAUM Yayınları, No. 3, 1989, s. 68-74; Ünal Tekinalp ve Gülören Tekinalp, Avrupa Birliği Hukuku, 2. Bas1, İstanbul, Beta, 2000, pp. 246-252; Sionaidh Douglas-Scott, Constitutional Law of the European Union, Harlow, Longman-Pearson Education, 2002, pp. 370-376; Hartley, op.cit., 2003, s. 414-432; Craig ve de Búrca, op.cit., s. 532-537.

${ }^{61}$ 16-17/62, Confédération nationale de producteurs de fruits et légumes v. Council, [1962] ECR 471. Konu ile ilgili olarak bkz. Rosa Greaves, "Locus Standi under Article 173 EEC When Seeking Annulment of a Regulation”, European Law Review, Cilt 11, 1986, s. 119.

${ }^{62}$ Arnull, op.cit., 1995, s. 21

${ }^{63}$ Ibid., s. 21.
} 
Divana göre, objektif olarak belirlenmiş durumlara uygulanan ve genel ve soyut biçimde saptanmış kişiler için hukuki sonuçlar öngören düzenlemeler tüzük karakterlidir. ${ }^{64}$ Divan, tüzüğün bu niteliğinin, sadece uygulanacağı kişilerin sayı, hatta kimliklerinin belli veya belirlenebilir olması nedeniyle ortadan kalkmayacağını belirtmektedir. Ancak, bunun için tasarrufun objektif ve genel olarak belirlenmiş hukuki veya maddi vakıalara uygulanıyor olması gerekmektedir. ${ }^{65}$ Divanın Calpak kararında geliştirdiği ve "soyut terminoloji testi" çerçevesinde, böyle bir durumda bireysel ilgili ispat etmek mümkün olsa bile, tasarruf genel düzenleyici işlem niteliğini kaybetmediğinden özel kişilerce aleyhine iptal davası açılması mümkün olmayacaktır. ${ }^{67}$

Buna karş1l1k, tüzük görünümündeki bir tasarruf gerçek anlamda düzenleyici bir işlem olmaktan çok idari işlem niteliğinde bir kararlar serisi oluşturuyorsa ve belli veya belirlenebilir kişilere uygulanıyorsa, söz konusu işlemin özel kişilerce iptal davasına konu edilebileceği Divan tarafından karara bağlanmıștır. ${ }^{68}$ Benzer șekilde Divan, bir tüzüğün genel bir kategoriye uygulanmakla birlikte bu kategoriye giren kişilere tek tek isim belirtmek suretiyle farklı muamele öngörmesi halinde tüzük olma niteliğini kaybedeceğine ve üstü örtülü bir kararlar serisi biçimine dönüşeceğine hükmetmiştir. ${ }^{69}$

Bir tasarrufun tamamının değil, bazı hükümlerinin iptali söz konusu olduğunda ise, özel kişilerin davacı olabilmesi açısından tasarrufun bütününün değil, ilgili hükümlerinin niteliği dikkate alınacaktır. Divan, gerçek anlamda bir tüzüğün de karar niteliği taşıyan hükümler içerebileceğini karara bağlamıștır. ${ }^{70}$ Ancak, bir başka kararında Divan, karar niteliği taşıyan hükümlerin, tasarrufun genel sistemi içinde ayrılmaz bir hukuki bütün oluşturması halinde, özel kişilerce dava edilemeyeceğine hükmetmiștir. ${ }^{71}$

Sonuç olarak, özel kişilerin bir tüzüğün iptalini talep edebilmesi için bu tasarrufun genel ve soyut olarak uygulanan bir düzenleyici işlem niteliğinde olmaması ve kendilerinin de bu tasarruftan etkilenen belli veya belirlenebilir bir gruba girmeleri gerekecektir.

\footnotetext{
${ }^{64}$ 6/68, Zuckerfabrik Watenstedt v. Council, [ 1968] ECR 409.

${ }^{65}$ 789-90/79, Calpak v. Commission, [1980] ECR 1949.

${ }^{66}$ Craig ve de Búrca, op.cit., s. 493-494.

67 Aşağıda görüleceği üzere Divan bu içtihadını Codorniu kararı ile bir ölçüde de olsa yumuşatmiştır.

${ }^{68}$ 87-130/77, 22/83, 9-10/84, Salerno v. Commission and Council, [1985] ECR 2523.

${ }^{69}$ 138/79, Roquette Frères v. Council, [1980] ECR 3333.

${ }^{70}$ 16-17/62, Confédération nationale de producteurs de fruits et légumes v. Council, [ 1962] ECR 471.

${ }^{71}$ 103-109/78, Société des Usines de Beauport v. Council, [ 1979] ECR 17.
} 
Konu ile ilgili olarak belirtilebilecek son husus ise, Divanın tüzük görünümündeki bir tasarrufun gerçekte karar niteliğinde olup olmadığını incelemesine karş1l1k, karar görünümündeki bir tasarrufun gerçek niteliğini inceleme yolunu tercih etmemesidir. ${ }^{72}$

\section{Doğrudan İlgi}

Bir Topluluk tasarrufunun davacının menfaatleri üzerinde, bir başka makam veya kişinin takdire dayalı işlemine gerek kalmaksızın etki meydana getirmesi halinde doğrudan ilgi mevcut sayılacaktır. ${ }^{73}$ Doğrudan ilginin ispatı için iptali istenen Topluluk tasarrufu ile bunun davacı üzerindeki etkisi arasında nedensellik bağının varlığı aranacaktır.

Bir tasarruf kendi içinde yeterli ve uygulama hükümlerine gerek bırakmayan bir kurallar dizisi ihtiva ediyorsa, söz konusu tasarrufun kendiliğinden uygulanması ve takdir hakkına yer bırakmaması nedeniyle davacıyı doğrudan ilgilendirdiği kabul edilebilir. ${ }^{74}$ Tasarruf üçüncü kişi tarafindan uygulanıyor olsa bile bu makama takdir hakkı bırakmıyorsa yine davacıyı doğrudan ilgilendirdiği kabul edilmektedir. ${ }^{75}$

Bununla birlikte, üçüncü kişinin tasarrufun uygulanmasında takdir hakkı varsa ve davacı da ancak bu uygulama sonucu tasarruftan etkileniyorsa doğrudan ilgi bulunmamaktadır. ${ }^{76}$ Buna karşılık, davacının üçüncü kişinin takdir hakkının nasıl kullanılacağı konusundaki niyetini, tasarruf kabul edildiği sırada hiçbir tereddüde yer bırakmayacak şekilde ortaya koyduğunu ispat etmesi durumunda doğrudan ilgi mevcut sayllabilecektir. ${ }^{\dagger 7}$

\section{Bireysel İlgi}

Davacı ilgili tasarruftan, tasarrufun kabul edildiği sırada hem teoride, hem de pratikte kapalı bir kategoriye dahil olması sebebiyle etkilendiğini ispat edebilirse bireysel olarak ilgili say 11 r. ${ }^{78}$ Divanın konu ile ilgili temel ilkeyi getiren Plaumann kararına göre, bireysel ilgi, ilgili tasarrufun o kişiyi, kendine özgü sıfat ve nitelikleri veya içinde bulunduğu ve onu diğer kişilerden ayıran koşullar nedeniyle, bireysel olarak belirli kılması durumunda mevcuttur. ${ }^{79}$

\footnotetext{
${ }^{72}$ Hartley, op.cit., 2003, s. 363.

${ }^{73}$ Weatherill ve Beaumont, op.cit., s. 273; Craig ve de Búrca, op.cit., s. 518.

${ }^{74}$ 294/83, Les Verts v. European Parliament, [1986] ECR 1339; 41-44/70, NV International Fruit Company v. Commission, [1971] ECR 411; C-386/96, Société Louis Dreyfus \& Cie v. Commission, [1998] ECR I-2309.

75 113/77, N.T.N. Toyo Bearing Company v. Council, [1979] ECR 1185.

${ }^{76}$ 69/69, Alcan v. Commission, [1970] ECR 385.

${ }^{77}$ 11/82, Piraiki-Patraiki v. Commission, [1985] ECR 207.

78 41-44/70, NV International Fruit Company v. Commission, [1971] ECR 411.

${ }^{79}$ 25/62, Plaumann v. Commission, [1963] ECR 95. Plaumann kararında ortaya konan "kapalı kategori” testinin özellikle ekonomik gerçeklere aykırılığına dayanan bir eleştirisi için $b k z$. Craig ve de Búrca, op.cit., s. 489.
} 
Görüldüğü üzere, bireysel ilgi şartı hukuki durumları tasarruftan etkilenen kişiler üzerinde yoğunlaşmaktadır. Burada tespit edilmesi gereken nokta bunların mensup oldukları grubun açık veya kapalı nitelikte olmasıdır. Dolayısıyla, Divanın 1990'ların ortalarına, ya da daha doğru bir ifade ile Codorniu $^{80}$ kararına dek izlediği içtihat uyarınca "soyut terminoloji" testinin yanı s1ra "kapalı kategori" 82 testinin de mevcudiyetinin ve bireysel ilgili ispatı bakımından her ikisinin de birlikte yerine gelmesinin zorunlu olduğu belirtilebilir. ${ }^{83}$

Toepfer kararı uyarınca, açık kategori, tasarruf yürürlüğe girdiğinde içine dahil olanların tam olarak belli olmadığ 1 bir grubu ifade eder. Buna karşı1ık kapalı kategori bir tasarrufun kabulü sırasında uygulanacağı kişilerin belli olması halinde söz konusudur. ${ }^{84}$

Kapalı bir kategoriye girenlerin bireysel ilgi şartını yerine getirmeleri nispeten kolay olmakla beraber, kişi açık bir kategoriye dahilse bireysel ilgili ispatı zorlaşacaktır. Nitekim, Divana göre, bir tasarruftan etkilenecek veya o tasarrufun uygulanacağı kişilerin sayısının ve hatta kimliklerinin önceden belirlenmesinin mümkün olması, bu tasarrufun onları bireysel olarak ilgilendirdiği sonucuna varılabilmesi için yeterli değildir. ${ }^{85}$ Divan, özellikle belli bir ticari faaliyette bulunmanın bireysel ilgiyi ispat için yeterli olmadığını vurgulamaktadır. ${ }^{86}$ Divana göre, bu tarz faaliyetler herkes tarafindan her zaman icra edilebilir ve dolayısıyla davacıyı bireysel olarak tefrik etmez; böyle bir durumda davacı en azından teorik olarak açık bir kategoride yer almaktadır. ${ }^{87}$

Bireysel ilgi şartı Divan tarafindan son derece katı biçimde uygulanmaktadır. Herhangi bir Topluluk tasarrufunun tek muhatabı olan bir firma bile açık bir kategori içinde sınıflandırılabiliyorsa, bu tasarrufun kendisini bireysel olarak ilgilendirdiği iddiasında başarısız olabilmektedir.

Aynı şekilde, Divan, teşebbüs birliklerinin iptal davası açma imkanını da son derece kısıtlayıcı şekilde yorumlamaktadır. Divana göre, üyelerinin temsilcisi sifatıyla hareket eden bir birlik, bu üyelerin genel menfaatlerini etkileyen bir tasarrufla bireysel olarak ilgili kabul edilemez.

Divanın konu ile ilgili daha liberal bir yaklaşım benimsemiş olduğu davalar çeşitli özellikleri nedeniyle ayrılmakta ve genel uygulamaya uygun

\footnotetext{
${ }^{80}$ Codorniu kararı aşağıda ele alınacaktır.

81 789-90/79, Calpak v. Commission, [1980] ECR 1949.

82 25/62, Plaumann v. Commission, [1963] ECR 95.

${ }^{83}$ Craig ve de Búrca, op.cit., s. 493-494.

${ }^{84}$ 106,107/33, Toepfer v. Commission, [1965] ECR 405.

${ }^{85}$ 123/77, UNICME v. Council, [1978] ECR 845.

${ }^{86}$ Wyatt ve Dashwood, op.cit., s. 127.

${ }^{87}$ 25/62, Plaumann v. Commission, [1963] ECR 95.
} 
olup olmadıkları konusunda şüphe uyandırmaktadır. ${ }^{88}$ Örneğin konu ile ilgili önemli bir içtihat oluşturan Les Verts kararında genel siyasi mülahazalar öncelikli olarak değerlendirilmiştir. ${ }^{89}$ Buna karşılık, İlk Derece Mahkemesinin yakın tarihli kararlarında birliklerin, usule ilişkin üyelerinin davacı sıfatına sahip olduğu durumlarda; iptali istenen düzenlemenin birliklere bazı özel hakları açıkça tanıması halinde veya birliğin, birlik sıfatıyla haklarının etkilenmesi durumunda davacı olmalarının kabul edildiğine rastlanmaktadır. ${ }^{90}$

Ancak, belli, kapalı ve ayırt edilebilir bir gruba girme şartının asıl yumuşak biçimde uygulandığı ve hatta terk edildiği dava konularını, rekabet politikası, devlet yardımları ve anti-damping soruşturmaları oluşturmaktadır. Bunlar çoğunlukla ilgili tarafların, şikayetçiler de dahil olmak üzere, görüşlerini sundukları özel bir usulün sonunda alınan yargı benzeri (quasijudicial) kararların iptali ile ilgili olarak açılan davalardır. Ancak, bu alanlardaki Divan içtihadının genel biçimde uygulanabilir olup olmadığ belirsizdir. $^{91}$ Örneğin, Topluluk rekabet politikasının uygulanmasında Komisyonun ihlalin gerçekleşmediği veya muafiyet tanındığı yolundaki kararına karşı şikayette bulunanların iptal davası açabilmesi kabul edilmiştir. ${ }^{92}$

Aynı şekilde, anti-damping önlemlerinin ancak tüzük niteliğinde bir tasarrufla alınabilmesi karşısında söz konusu tüzükte adı geçen veya hazırlık soruşturmasına katılan kişi veya firmaların bireysel ilgi şartını yerine getirdiğine Divan tarafından hükmedilmiştir. ${ }^{93}$ Hatta bu durumda teşebbüs birliklerinin bile davacı olabileceği belirtilmiştir.

Benzer biçimde, devlet yardımları ile ilgili şikayette bulunan veya soruşturmada görüşlerine başvurulan ve prosedürün işleyişine önemli etkide bulunanların pazardaki konumları ilgili Komisyon kararına konu yardımdan önemli ölçüde etkilenmişse iptal davası açabilecekleri belirtilmektedir. ${ }^{94}$ Tüm bu kararlarda davacıların iptal davası açabilmeleri ilgili tasarrufun kabulünde geçerli süreçte oynamış oldukları role dayanılarak kabul edilmiştir. ${ }^{95}$

\footnotetext{
${ }^{88}$ Arnull, op.cit., 1995, s. 28.

${ }^{89}$ Wyatt ve Dashwood, op.cit., s. 128.

${ }^{90}$ T-122/96, Federolio v. Commission, [1997] ECR II-1559.

${ }^{91}$ Arnull, op.cit., 1995, s. 30.

92 26/76, Metro v. Commission, [1971] ECR 1875.

${ }_{93}$ 239-275/82, Allied Corporation v. Commission, [1984] ECR 1005.

${ }^{94}$ 169/84, COFAZ v. Commission, [1986] ECR 391.

${ }^{95}$ Arnull, op.cit., 1995, s. 34.
} 
"Kapalı Kategori” ve "Soyut Terminoloji” Kriterlerinin Bireysel İlginin Saptanmasındaki Rolü

Peki, özel kişilerin davacı olabilmesi için gerçekten bu üç şartın tasarrufun karar niteliğinde olması, ilgiliyi doğrudan ilgilendirmesi ve bireysel olarak ilgilendirmesi- bir arada $\mathrm{m} 1$ yerine getirilmesi gereklidir? 230. maddenin 4. paragrafı bir tüzüğü iptal ettirmeye çalışan özel kişinin üç koşulu da bir arada yerine getirmesi gerektiği şeklinde sonuç çıkarmaya uygundur. Divan da çeşitli kararlarında davacı olabilmek için her üç şartın da birlikte yerine getirilmesi gerektiğini belirtmiştir. ${ }^{96}$

Ama aslında tüzük adını taşıyan bir tasarrufun gerçekte karar olduğunu ortaya koymak için kullanılan "sınırlı sayıda kişiyi etkilemesi" ya da davacının "kapalı bir kategoriye dahil olması" kriterleri aynı zamanda bu kişilerin kendilerine özgü sıfat ve nitelikleri veya içinde bulundukları ve onları diğer kişilerden ayırt eden bir takım şartlar nedeniyle, ferden belirli kılınması şeklinde tanımlanan bireysel ilgi kriterinin de yerine geldiği anlamını taşıyacak mıdır?" Dolayısıyla "soyut terminoloji" testi, "kapalı kategoriye dahil olma" kriteri gerçekleştiğinde bile ayrıca aranmaya devam edecek midir? Bu açıdan bakıldığında aslında yerine getirilmesi gereken iki şart var gibi gözükmektedir; bireysel ilgi ve doğrudan ilgi. Bireysel ilgi varsa söz konusu tasarruf zaten tüzük değil, karardır.

Divanın son zamanlardaki içtihadı da bu görüşü benimsemeye başladığını gösterir nitelikte ipuçları içermektedir. ${ }^{98}$ Konu ile ilgili Extramet kararında Hukuk Sözcüsü Jacobs, tasarrufun karar niteliğinde olması koşulunun bireysel ilgi koşulundan bağımsız şekilde mevcut olamayacağını belirtmektedir. ${ }^{99}$ Divanın kararı daha muğlak olmakla birlikte, burada da aynı görüşün benimsendiği anlaşılmaktadır. Divana göre, bir tasarruf tüzük karakterini kaybetmeden de belirli kişileri bireysel olarak ilgilendirebilir ve dolayısıyla bu kişiler tarafından açılacak iptal davasına konu olabilir. Bir başka şekilde formüle edilirse, herhangi bir tasarrufun gerçek anlamda tüzük niteliğinde olduğuna hükmedilmesi, söz konusu tasarrufun davaciyı doğrudan ve bireysel olarak ilgilendirmediğinin ortaya konmas1 anlamına gelecektir. $^{100}$

Codorniu davasında verilen karar ise bu konuda Divanın daha esnek bir tutum benimsemeye başladığına ilişkin yorumların ağırlık kazanmasına yol açmıştır. ${ }^{101}$ Görünüşe göre Divan bu davada verdiği karar ile özel kişilerin

\footnotetext{
${ }^{96}$ 307/81, Alusuisse v. Council and Commission, [1982] ECR 3463.

${ }^{97}$ Wyatt ve Dashwood, op.cit., s. 129-130.

${ }^{98}$ Ancak aşağıda ortaya konmaya çalışılacağı üzere, bu yönde kesin, tutarlı ve açık bir içtihat oluştuğunu ileri sürmek zordur. Özellikle aşağıda ele alınacak UPA kararının ardından Divanın bu görece esnek yaklașımı terk ettiği de ileri sürülebilir.

${ }^{99}$ C-358-89, Extramet Industrie v. Council, [1991] ECR I-2501.

${ }^{100}$ C-213/91, C-264/91, Albertal and Others v. Commission and Council, [1993] ECR I-3177.

${ }^{101}$ C-309/89, Codorniu v. Commission, [1994] ECR I-1853.
} 
iptal davası açabilme koşulları hakkında kesin bir içtihat oluşturma ve yol gösterme çabasına girişmiştir. ${ }^{102}$ Hukuk Sözcüsü Lenz'e göre, bir tasarrufun gerçek niteliğinin karar olup olmadığını saptamak üzere uygulanacak test ile tasarrufun davacıyı bireysel olarak ilgilendirip ilgilendirmediğini saptamak üzere uygulanacak test arasında bir ayrım yapmak son derece zordur. ${ }^{103}$

Aynı davada, Divan da, gerçek veya tüzel bir kişinin 230. madde uyarınca bir tüzüğün iptalini talep edebilmesi için söz konusu tüzüğün hükümlerinin aslında davacıyı doğrudan ilgilendiren bir karar niteliğinde olması gerektiğine karar vermiştir. Divan ayrıca tasarrufun uygulandığ 1 kişilerin sayı ve kimliklerinin belirlenebilmesinin söz konusu tasarrufun hukuki niteliğinin tartışılması için yeterli olmadığını da vurgulamaktadır. $\mathrm{Bu}$ görüş davacı için olumsuz sonuçlar doğurmaya müsait görünmekle birlikte, Divan, kararında şu ifadelere yer vermektedir:

"Her ne kadar 173. maddenin [230. madde] 4. paragrafinda sayılan kriterlere göre söz konusu tasarruf niteliği ve uygulama alanı itibariyle ilgili tacirlere genel olarak uygulanmakta olduğundan genel düzenleyici işlem görünümünde olsa da bu durum ilgili tasarrufun söz konusu tacirlerin bir kısmını bireysel olarak ilgilendirmesine engel değildir." 104

Divan, daha sonra Plaumann davasında bireysel ilginin mevcudiyeti için ortaya koyduğu kriterleri yinelemiştir. Bu kriterler 1şı̆̆ında davacı kendisini tüm diğer tacirlerden ayıran belirli özellik ve niteliklere sahip olduğundan söz konusu tasarrufun iptalini talep imkanına sahiptir. ${ }^{105}$

Yukarıdaki içtihat 1şığında bir tüzük aleyhine iptal davası açmak isteyen özel davacının sadece bireysel ve gerekli hallerde de doğrudan ilgiyi ispat etmesi yeterli olacak; tasarrufun gerçekte karar niteliğinde olması şartı bundan böyle aranmayacaktır. "Kapalı kategori" kriteri gerçekleştiğinde "soyut terminoloji" kriterinin de ayrıca yerine gelmesine gerek kalmamalıdır. Tasarruf genel ve soyut olarak ifade edilmiş olabilir, ama yine de belli kişileri bireysel olarak ilgilendirebilir. Aynı zamanda bireysel ilgi şartı da daha esnek hale getirilmiştir. Buna göre, tasarrufun davacinın faaliyetleri üzerinde ciddi bir etki göstermesi yeterli kabul edilebilecektir. ${ }^{106}$ Ancak, yine de bireysel ilginin ispatında genel olarak Plaumann formülü geçerli olmaya devam etmektedir. ${ }^{107}$

\footnotetext{
102 Anthony Arnull, "Private Applicants and the Action for Annulment since Codorniu", Common Market Law Review, Cilt 38, 2001, s. 51-52.

${ }^{103} B k z$. Hukuk Sözcüsü Lenz'in Codorniu davasındaki görüşü.

${ }^{104}$ C-309/89, Codorniu v. Commission, [1994] ECR I-1853.

105 Arnull, op.cit., 1995, s. 38-39; Weatherill ve Beaumont, op.cit., s. 258.

${ }^{106}$ Arnull, op.cit., 1995, s. 39.

${ }^{107}$ Craig ve de Búrca, op.cit., s. 496.
} 
Gerçekten de, 230. madde metninin özel kişilerin tüzüklere karşı dava açma imkanını, başkalarını muhatap alan ancak kendilerini doğrudan ve bireysel olarak ilgilendiren kararlara karşı dava açma hakkı ile aynı şekilde düzenlediği biçiminde yorumlanmasının daha uygun olacağı açıktır. $\mathrm{Bu}$ durumda özel kişilerin tüzüklere karşı dava açma hakkı, tasarrufun adı veya şekli ve içeriğinden çok, ilgili üzerinde doğurduğu etki çerçevesinde belirlenecektir. ${ }^{08}$

230. maddenin yorumunda bu yaklaşım benimsenirse özel kişilerin hem tüzüklere, hem de başkalarını muhatap alan kararlara karşı dava açma yetkisinin mevcudiyeti bireysel ve doğrudan ilgi şartlarının yerine gelmesi ile belirlenecektir.

Codorniu Kararı Sonrası Gelişmeler ve Özel Kişilerin Davacı Olabilmeleri Bakımından Mevcut Durum

Divanın Codorniu kararından sonra iptal davası açmak bakımından özel kişilerin yerine getirmesi gereken koşulların yumuşatıldığına ve Divan içtihadında bu yönde yaklaşımların süreceğine ilişkin görüşlere doktrinde sıklıkla rastlandığı görülmektedir. ${ }^{109}$ Özellikle İlk Derece Mahkemesine imtiyazlı olmayan davacılar tarafından açılan iptal davalarına bakma yetkisinin tanınmas ${ }^{110}$ ile Divanın bu alandaki içtihadını yumuşatmayı tercih edebileceği öne sürülen bir argüman olmuştur. ${ }^{111}$ Ancak, İlk Derece Mahkemesi başlangıçta bu alanda Divan içtihadını değiştirecek bir yaklaşım sergilemekten kaçınarak kararlarında bir yandan Divanın Calpak kararında geliştirilen soyut terminoloji ya da çifte gereklilik testini uygulamayı sürdürmüş̧; diğer yandan da gerçek bir yasama işleminin bile istisnai durumlarda bireysel ilgi doğurabileceğini kabul etmekle birlikte Plaumann formülünü, yani kapalı kategoriye dahil olma gerekliliğini bireysel ilginin tespitinde kullanmaya devam etmiştir. ${ }^{12}$

Codorniu kararındaki hak ihlaline uğrama kıstasının genel bir uygulamaya tabi olduğunu ileri sürme imkanı Divanın daha sonraki içtihatları ile ortadan kalkmış gibi görünmektedir. ${ }^{113}$ Örneğin hem Buralux ${ }^{114}$ hem de Greenpeace ${ }^{115}$ kararlarında İlk Derece Mahkemesi ve kararların temyizinin ardından Adalet Divanı, davacıların taleplerini reddederek,

\footnotetext{
${ }^{108}$ Arnull, op.cit., 1995, s. 16.

${ }^{109}$ Craig ve de Búrca'nın Divan ve İlk Derece Mahkemesinin Codorniu kararı sonrasındaki içtihadına hakim olan üç farklı tutumla ilgili yaklaşımları için bkz. Craig ve de Búrca, op.cit., s. 496-500.

110 93/350 sayıl1 Konsey Kararl (Council Decision), OJ 1993 L 144/21 ve 94/149 say1l Konsey Kararl (Council Decision), OJ 1994 L 66/29.

${ }_{111}^{11}$ Weatherill ve Beaumont, op.cit., s. 259-260.

112 Ibid.,s. 259-260.

${ }^{113}$ Arnull, op.cit., 2001, s. 31.

${ }^{114}$ C-209/94, Buralux SA and Others v. Council, [1996] ECR I-615

${ }^{115}$ C-321/95, Greenpeace and Others v. Commission, [1998] ECR I-1651
} 
kendilerini ulusal mahkeme nezdinde ilgili Topluluk düzenlemesinin hukuka aykırılığını iddia etmeye ve böylece ön karar yoluyla konuyu önlerine getirmeye çalışmaya davet etmiştir. ${ }^{116}$ Ancak, örneğin Greenpeace kararında Divan kararını "kapalı kategoriye dahil olmak" formülü yerine, yasa koyucunun işlemi yaparken spesifik olarak davacıyı hedef alıp almadığ 1 üzerine inşa etmektedir. ${ }^{117}$ Dolayısıyla bugün için Plaumann formülü, ancak ve istisnai biçimde, iptali istenen tasarrufun davacının haklarını ihlal etmesi ${ }^{118}$ ya da davaciya yönelik bir yükümlülüğün yerine getirilmemesi ${ }^{119}$ durumunda davacı lehine yumuşatılarak yorumlanabilmektedir. ${ }^{120}$

Özel kişilerin iptal davası açabilmeleri konusundaki içtihadın yumuşatılacağı konusundaki ihtiyatlı iyimserliği tetikleyen bir başka gelişme ise, Hukuk Sözcüsü Jacobs'in Unión de Pequeños Agricultores (UPA) davasında verdiği görüştür. ${ }^{121}$ Hukuk Sözcüsüne göre, bir tasarrufun ilgilinin menfaatleri üzerinde olumsuz etki doğurması veya böyle bir etki doğurması ihtimalinin mevcudiyeti halinde bireysel ilgi koşulunun gerçekleştiği kabul edilmelidir. ${ }^{122}$ Jacobs' a göre böyle bir durumda davacılar gerçek bir hukuki telafi ve yaptırım yoluna başvurabilecek bir yargı organı önünde dava açma ve hukuki koruma talep etme imkanına sahip olabileceklerdir. Ayrica, mevcut durumda bir tasarruftan etkilenen kişilerin sayısı ne kadar fazla ise etkili bir hukuka uygunluk denetimine başvuru imkanlarının o derece azalması anormal bir durum teşkil etmektedir. Davacı olma koşulları ile ilgili olarak uygulanan; çok karmaşık ve öngörülemez kurallar içeren testin çok daha basit bir testle değiştirilmesi ve Topluluk hukukunda hukuki denetim ile ilgili davalarda vurgunun kabul edebilirlikle sınırlı şekli meselelerden maddi içeriğe doğru kaydırılması gerekmektedir. Bu tarz bir yeniden yorum ise, Divan içtihadına hakim olan Topluluk kurumlarının yetkilerindeki artışa cevap amaçlı olarak hukuki korumanın kapsamının arttırılmasına yönelik genel eğilime uygun düşecektir.

Hukuk Sözcüsüne göre davacı statüsünün kapsamının genişletilmesine karşı argümanlar ikna edici değildir. Ne 230. maddenin lafzının böyle bir yorumu olanaksız kıldığı, ne de hukuka aykırılık potansiyeli taşıyan

\footnotetext{
${ }^{116}$ C-209/94, Buralux SA and Others v. Council, [1996] ECR I-615 ve C-321/95, Greenpeace and Others v. Commission, [1998] ECR I-1651.

${ }^{117}$ Weatherill ve Beaumont, op.cit., s. 268.

${ }^{118}$ C-309/89, Codorniu v. Commission, [1994] ECR I-1853.

${ }_{119}$ T-480 ve 483/93, Antillean Rice Mills NV v. Commisson, [1995] ECR II-2305.

${ }^{120}$ Craig ve de Búrca, op.cit., s. 502-503.

${ }^{121}$ C-50/00 P, Unión de Pequeños Agricultores v. Council, [2002] ECR I-6677.

122 Bkz. Hukuk Sözcüsü Jacobs'un (UPA) davasindaki Görüşü: C-50/00 P, Unión de Pequeños Agricultores v. Council, [2002] ECR I-6677. Burada yararlanıldığı biçimde bu görüşün bir özeti için bkz. Craig ve de Búrca, op.cit., s. 500-501.

123 230. maddenin 5. paragrafi uyarınca iptal davası, tasarrufun yayımı veya davaciya bildirimi ya da davacı tarafından öğrenilmesinden itibaren 2 ay içinde açılabilir. Süre hak düşürücü süre niteliğindedir.
} 
düzenlemelerin yargısal denetimin dışında bırakılması verimli ve etkili işleyen bir yasama ya da idare ihtiyacı ile gerekçelendirilebilir. Ayrıca, 230. maddenin 5. paragrafinda düzenlenen dava zamanaşımı süresi ${ }^{123}$ ve doğrudan ilgi koşullarının varlığı 1şığında İlk Derece Mahkemesinin aşırı iş yükü ile karşı karşıya kalması endişesi de haklı görülemez. İçtihadın uzun süredir değişmediği doğru olmakla birlikte, bir değişikliğin tam zamanıdır. Çünkü içtihat istikrarlı olmayıp yeni tarihli pek çok davada koşulların yumuşatıldı̆̆ 1 ve böylece sorunun iyice karmaşık ve öngörülemez bir hal aldığı görülmektedir. Ayrıca mevcut içtihat üye devletlerin bu alanda gittikçe daha liberalleşen içtihadıyla da uyumsuzdur. İlk Derece Mahkemesinin kuruluşu ve gittikçe daha fazla yetkinin bu mahkemeye devri, oluşabilecek dava yükünü hafifletmeye yardımcı olacaktır. Bundan başka, Divanın ulusal mahkemelerde etkili yargisal/hukuki korumanın temini ilkesi alanındaki içtihadı ile Topluluk mahkemeleri önünde davacı olma şartına getirilen dar ve kısıtlayıcı yorumu bağdaştırabilmek de gittikçe güçleşmektedir.

$\mathrm{Bu}$ görüşün ardından İlk Derece Mahkemesi tarafından Jégo-Quéré ${ }^{124}$ davasında verilen karar da bu yöndeki olumlu gelişmelerin bir göstergesi olarak nitelendirilmiştir. Söz konusu kararında İlk Derece Mahkemesi, ilgili davada Topluluk düzenlemesinin dolaylı biçimde hukuka uygunluk denetimine tabi tutulmasının önünde önemli engeller bulunduğunu belirtmektedir. Yargı yollarına başvuru imkanının hukukun üstünlüğüne dayalı bir Topluluk oluşturmanın temel gerekliliklerinden biri oluşu ve 234 . maddede düzenlenen ön karar davasının veya 288. maddenin 2. paragrafinda düzenlenen tazminat davası imkanının mevcudiyetinin yeterli bir telafi yolu oluşturmayışı karşısında "soyut terminoloji” ya da "kapalı kategori",125 testleri ile sıkı sıkıya bağlı kalmak olumsuz sonuçlara yol açabilecektir. Bu nedenle, etkili yargısal korumayı temin etmek amacına yönelik olarak genel biçimde uygulanma kabiliyetine sahip bir tasarrufun, haklarının kısıtlanması veya borç yüklenmesi yoluyla bir kişinin hukuki durumunu kesin ve dolaysız (immediate) biçimde etkilemesi durumunda söz konusu kişiyi bireysel olarak ilgilendirdiği sonucuna varılacaktır. Tasarruftan kendisi gibi etkilenen, ya da etkilenebilecek olan kişilerin sayısı ya da konumunun söz konusu kişi bağlamında bireysel ilginin ispatı bakımından önemi ve ilgisi bulunmamaktadır. ${ }^{26}$ İlk Derece Mahkemesinin kararında da vurgulandı $\breve{g}_{1}$ üzere burada hukuka uygunluk denetimine tabi tasarruf gerçek anlamda genel uygulanırlığ1 ve kapsamı olan bir düzenlemedir. Bir "kararlar toplamı" niteliğinde olmadığı gibi soyut terminoloji kıstasına da uygundur. Buna

\footnotetext{
${ }^{124}$ T-177/01, Jégo-Quéré et Cie SA v. Commission, [2002] ECR II-02365.

125 İlk Derece Mahkemesi somut davada bu şartın gerçekleşmediğine, yani tasarrufun davacıyı bireysel olarak ilgilendirmediğine, Codorniu ve Extramet davalarında ortaya konan istisnai şartların da yerine gelmediğine hükmetmiştir.

${ }^{126}$ T-177/01, Jégo-Quéré et Cie SA v. Commission, [2002] ECR II-02365.
} 
rağmen, böyle bir tasarruf için bile ayrıca bireysel ilginin ispatı mümkün olmalıdır.

Adalet Divanının özel kişilerin davacı olmasına ilişkin koşulları sistemli, kesin ve açık biçimde yumuşatmaya hazır olduğu yönündeki beklenti, Divanın Unión de Pequeños Agricultores (UPA) kararında, aynı davada Hukuk Sözcüsü Jacobs'un görüşünü ve Jégo-Quéré kararında da İlk Derece Mahkemesinin yaklaşımını benimsemeyerek, Codorniu öncesi içtihadına geri dönüşünü simgeleyen yorumu ile bugün için gerçekleşmemiş görünmektedir.

Divan, bu kararı ile, açıkça ifade etmese bile, İlk derece Mahkemesinin Jégo-Quéré içtihadını bozmuş görünümü vermektedir. ${ }^{127}$ Divana göre, UPA davasında davacının ulusal mahkemeler önüne konuyu taşıması ve 234. madde prosedürünü işletmesi mümkün değildir; tüzüğün uygulanması ile ilgili bir ulusal önlem bulunmadığı gibi, iç hukukta tüzüğe aykırı herhangi bir düzenlemeye de rastlanmamaktadır. Böyle bir durumda sırf etkili hukuki koruma sağlanması amacıyla 230. maddenin lafzına aykırı bir yorumla bireysel ilgi şartını yerine getirmeyen davacıya iptal davası açma imkanı tanınmalı midır?

Divan, kararında ne Hukuk Sözcüsünün görüşüne, ne de İlk Derece Mahkemesinin Jégo-Quéré kararına uymayı seçmiştir. Divan ayrıca önündeki davanın bir istisna teşkil ederek etkili koruma ilkesi gereği davacılık sıfatının kabulü ile sonuçlanması gerektiğini de düşünmemektedir. Bunun yerine Divan, özel kişilerin iptal davası açabilmesi hakkındaki yerleşik içtihadını ve bu çerçevede Plaumann formülünün uygulanmasını sürdürmeyi tercih etmiştir. Divana göre, 230. maddeye getirilebilecek, özellikle etkili hukuki koruma ve yaptırımlarla ilgili eleştirilerin haklılığg belirleyici olmaktan uzaktır. Divan, bu eleştirileri bir ölçüde haklı gördüğünü belirtmekle birlikte, madde metni ile bağli olduğunu, madde metnini değiştirmenin ise üye devletlerin yetkisine girdiğini belirtmektedir. Şu anki durumda bireysel ilgi gerçekleşmeden, hangi durumda ve koşulla olursa olsun, bireylerin iptal davası açma yetkisi bulunmamaktadır. ${ }^{128}$

Buna karşı1ık, Divan, Avrupa Topluluğunun hukuka dayalı bir topluluk olduğunun da altını çizerek, kurumlarının tasarruflarının hukuka uygunluk denetimine tabi olması gerektiğini belirtmektedir. ${ }^{129}$ Bu gerekliliğin başka herhangi bir hukuk yolu ya da yaptırım bulunmayan hallerde bireysel ilgi koşulunun yumuşatılması sonucunu doğurup doğurmayacağı ise, Divanın bundan sonraki içtihadı ile belirlenecektir.

\footnotetext{
${ }^{127}$ Nitekim, Komisyon, UPA kararının ardından Jégo-Quéré kararının temyizi için ATAD önünde dava açmıştır. Bkz. C-263/02 P Commission v. Jégo-Quéré.

${ }^{128}$ C-50/00 P, Unión de Pequeños Agricultores v. Council, [2002] ECR I-6677, paragraf 37.

${ }^{129}$ C-50/00 P, Unión de Pequeños Agricultores v. Council, [2002] ECR I-6677, paragraf 38.
} 


\section{Topluluk Yargı Organlarının Özel Kişilerin Davacı Olması ile İlgili İçtihadının Değerlendirilmesi ${ }^{130}$}

Divanın UPA davasında vermiş olduğu karar, 1990'ların ikinci yarısından beri genel olarak içtihadına hakim olmaya başlayan temkinli ve ihtiyatll tutumun yeni bir göstergesi olarak yorumlanabilir. ${ }^{131}$ Divan, kurucu antlaşmayı genişletici yoruma tabi tutmak ya da aktivist olarak nitelenebilecek bir yaklaşım benimsemek yerine madde metni ile bağlı kalmayı tercih etmektedir. Kurucu antlaşmanın boşluk ya da eksikliklerini yargısal içtihat yoluyla doldurma girişimleri, özellikle Avrupa bütünleşmesinin demokratik meşruiyetinin tartışma konusu olduğu günümüzde Divanın uygun bulduğu bir yaklaşım değildir. Siyasi organların ve üye devletlerin bu konuda sorumluluklarını yerine getirmesi Divana göre daha uygun olacaktır. Böylece Divan, anayasal sorumluluklarına açık bir sınır getirmiş olmaktadır. ${ }^{132}$

Yukarıda incelediğimiz davalar 1şı̆̆ında, Divanın diğer pek çok alanda yıllardır izlediği madde metni ile bağlı kalmayı reddeden, amaçsal ve aktivist yorum yöntemini ve benimsediği etkili hukuki koruma ve yaptırımlar ile bireysel hakların etkili biçimde korunması ilkelerini, bireylerin Topluluk tasarruflarına karşı dava açmaları bakımından başlangıçtan beri benimsemediği, bugün için de aynı tutumunu sürdürdüğü tespitini yapabilmekteyiz. ${ }^{133}$ Divanın bu tutumunun nedenlerinin arasında Divanın kendisini bir temyiz mahkemesi gibi konumlandırma ve aşırı iş yükünden kurtarma isteğinin olduğu görüșünün, ${ }^{134}$ kurucu antlaşmanın lafżının böyle bir yaklaşımı gerekli kıldığı argümanının, ${ }^{135}$ özellikle Ortak Tarım Politikası gibi geniş takdir hakkının geçerli olduğu alanlarda Topluluk kurumlarının hareket serbestisini kisitlamama ve Divanın kendisini bu kurumların yerine

\footnotetext{
${ }^{130} \mathrm{Bu}$ konuda genel olarak bkz. Angela Ward, Judicial Review and the Rights of Private Parties in EC Law, Oxford-New York, Oxford University Press, 2000; Iris Canor, "Harmonizing the European Community's Standard of Judicial Review", European Public Law, Cilt 8, 2002, s. 135-166; Albertina Albors-Llorens, "The Standing of Private Parties to Challenge Community Measures: Has The European Court Missed the Boat?", Cambridge Law Journal, Cilt 62, 2003, s. 72-92.

${ }^{131}$ Divan içtihadından bir örnek için bkz. C-376/98, Germany v. Parliament and Council (Tobacco Advertising Case), [2000] ECR I-8419. Bu alanda bir inceleme için bkz. Sanem Baykal, "Avrupa Birliği Anayasalaşma Sürecinde Adalet Divanı'nın Rolü: Divanın Ulusal Mahkemelerle İlişkileri ve Yorum Yetkisinin Sınırları Bağlamında Bir Analiz”, Ankara Avrupa Çalışmaları Dergisi, Cilt 4, No. 1, Güz 2004, s. 121-149.

${ }^{132}$ Angela Ward, "Judicial Architecture at the Cross-Roads: Private Parties and Challenge to EC Measures Post-Jégo-Quéré”, The Cambridge Yearbook of European Legal Studies, Cilt 4, 2001, s. 442.

${ }^{133}$ Benzer görüş için $b k z$. Albors-Llorens, op.cit., 1996, s. 182.

${ }^{134}$ Hjalte Rasmussen, "Why is Article 173 Interpreted against Private Plaintiffs?", European Law Review, Cilt 5, 1980, s. 122-127.

${ }^{135}$ Christopher Harding, "The Private Interest in Challenging Community Action", European Law Review, Cilt 5, 1980 s. 354-355.
} 
koyarak karar vermek gibi istenmeyen bir durumla karşı karşıya kalmama arzusunun varlığının, ${ }^{136}$ yargısal benzeri (quasi-judicial) prosedürlerde, örneğin anti-damping, devlet yardımı ve rekabet politikası alanlarında davacı olma koşullarının çok daha liberal biçimde uygulandığı görüşünün, ön karar davası yoluyla dolaylı biçimde de olsa tasarrufların hukuka uygunluk denetiminin gerçekleştirilme imkanının mevcudiyeti yaklaşımının ${ }^{137}$ altı çizilebilir.

Tüm bu argümanların Topluluk hukukunun gereksinimleriyle çok da bağdaşmadığı açıktır. Örneğin, Divan, özel kişilerin iptal davası açma koşullarını dar yorumlamak yoluyla iş yükünü hafifletmiş olmamakta, alternatif yaptırım ve hukuk yolu olarak önerdiği 234. madde prosedürü ile önüne gelebilecek hukuka uygunluk denetimi davaları dolayısıyla aynı problemi yaşamaya devam etmektedir. ${ }^{138}$ Her ne kadar, 230. madde uyarınca iptal davası açma imkanına sahip özel kişilerin bu davayı açmamaları halinde ilgili Topluluk düzenlemesinin hukuka aykırı olduğu iddiasını 234. madde prosedürü uyarınca gündeme getirmeleri Divan tarafından kabul edilmemekteyse de, hem iş yükünün azaltılması, hem de etkili uygulama gereksinimlerinin bu yöntemle karşılanması çok da gerçekçi görünmemektedir. $\mathrm{Bu}$ tarz davalarda ulusal mahkemenin iddiayı ciddiye alması ve konuyu ön karar yoluyla Divan önüne götürmesi her durumda mümkün olmadığı gibi, iddiayı ciddiye alması durumunda da ihtiyati tedbir ya da yürütmenin durdurulması kararı veremeyeceğinden ortaya çıkabilecek zararların önüne geçilmesi her durumda gerçekleşememektedir. ${ }^{139}$ Üstelik, özel kişilerin davacı olabilme koşulları hakkındaki Divan içtihadının karmaşık ve belirsiz yapısı karşısında bireylerin 230. madde çerçevesinde dava açmaları mümkünken bu imkanlarını kullanmadıkları gerekçesiyle konuyu ulusal mahkeme önünde ileri sürmelerinin engellenmesinin hakkaniyete ve bireysel hakların etkili korunması ilkesine ne ölçüde uygun olduğunun da ayrıca tartışılması gerekir. ${ }^{140}$

Esasen hukuka aykırı bir tasarrufun iptal davasına konu edilememesi nedeniyle uygulanmasının Topluluk hukukunun etkili işleyişini ve bireysel hakların etkili korunmasını tehlikeye düşürme ihtimalinin yol açacağı

${ }^{136}$ Paul Craig, "Legality, Standing and Substantial Review in Community Law", Oxford Journal of Legal Studies, Cilt 17, 1994, s. 507; Craig ve de Búrca, op.cit., s. 513-514.

${ }^{137}$ Söz konusu görüşlerle ilgili ayrıntılı bir inceleme için bkz. Craig ve de Búrca, op.cit., s. 510-515.

${ }_{138}$ Ön karar davası hakkında ayrıntılı bir inceleme için bkz. Füsun Arsava, Roma Antlaşmasında Önkarar Prosedürü ve Bu Prosedür Çerçevesinde Doğan Sorunlar, Ankara, ATAUM Yayınları, No: 5, 1989.

139 Adalet Divanının yerinde bir içtihat oluşturan Foto Frost kararı uyarınca Topluluk tasarruflarının yargisal denetimi sadece Topluluk yarg1 organları tarafindan gerçekleştirilebileceğinden böyle bir durum kaçınılmazdır. Bkz. 314/85, Foto-Frost v. Hauptzollamt Lübeck-Ost, [1987] ECR 4199.

${ }^{140}$ Benzer görüş için bkz. Ward, op.cit., 2001, p. 424. 
sorunların, iş yükü artışı, kurucu antlaşmanın lafzına bağlı kalma ihtiyacı ya da etkili ve verimli işleyen idare gereksinimi karşısında ağır basması gerektiği savunulabilir. Özellikle Avrupa Birliği ile vatandaşları arasındaki uzaklığın kapatılması ve demokratik meşruiyeti güçlendirme gereksinimlerinin yoğun olarak hissedildiği günümüzde, hem katılım, hem de yargısal denetim bakımından vatandaşların $A B$ yasama ve karar süreçlerindeki rolünün yeniden gözden geçirilmesi yerinde olacaktır. ${ }^{141}$ Anlaşıldığ1 üzere Divana göre de özel kişilerin iptal davası açma koşullarında bir iyileştirme ve esnekliğe ihtiyaç vardır; ancak burada görev ve sorumluluk yargı organlarına değil, kurucu antlaşmaların efendisi olan üye devletlere düşmektedir. ${ }^{142}$

\footnotetext{
${ }^{141}$ Benzer bir görüş için $b k z$. Carol Harlow, "Towards a Theory of Access for the European Court of Justice", Yearbook of European Law, Cilt 12, 1992, s. 213.

14229 Ekim 2004 tarihinde Roma'da imzalanan, ancak Fransa ve Hollanda'da halkoyu ile reddedilmesinin ardından onay süreci çıkmaza giren Avrupa Birliği Anayasal Antlaşması III365. maddesinde iptal davasını yeniden düzenlemektedir. Buna göre:

"1. Avrupa Birliği Adalet Divanı, Avrupa yasalarının ve çerçeve yasalarının, tavsiyeler ve görüşler haricindeki Konsey, Komisyon ve Avrupa Merkez Bankası tasarruflarının ve üçüncü şahıslar nezdinde hukuki sonuçlar doğuran Avrupa Parlamentosu tasarruflarının hukuka uygunluğunu inceler. Avrupa Birliği Adalet Divanı, aynı zamanda Birlik organlarının, ofislerinin ve ajanslarının üçüncü şahıslar nezdinde hukuki sonuçlar doğurmayı amaçlayan tasarruflarının hukuka uygunluğunu inceler.

2. Bu amaçla, Avrupa Birliği Adalet Divanı, bir Üye Devlet, Avrupa Parlamentosu, Konsey veya Komisyon tarafından yetkisizlik, esaslı şekil şartlarının ihlali, Anayasa'nın veya onun uygulanmasına ilişkin herhangi bir hukuk kuralının ihlali veya yekinin kötüye kullanılması gerekçeleriyle açılan davalarda, yargılama yetkisine sahiptir.

3. Avrupa Birliği Adalet Divanı, Sayıştay, Avrupa Merkez Bankası ve Bölgeler Komitesi tarafından kendi yetkilerinin korunması amacıyla açılan davalarda, 1. ve 2. paragraflarda öngörülen koşullarda yargılama yetkisine sahiptir.

4. 1. ve 2. paragraflarda öngörülen koşullar altında, herhangi bir gerçek veya tüzel kişi, kendisine yöneltilen veya kendisini doğrudan ve bireysel olarak ilgilendiren bir tasarrufa karşı, ayrıca kendisini doğrudan ilgilendiren ve uygulama önlemleri gerektirmeyen bir düzenleyici tasarrufa karşı dava açabilir.

5. Birlik organlarını, ofislerini ve ajanslarını kuran tasarruflar, gerçek veya tüzel kişiler tarafından, bu organların, ofislerin ve ajansların hukuki sonuçlar doğuran tasarrufları aleyhine açılan davalarla ilgili özel koşullar ve düzenlemeler belirleyebilir.

6. Bu maddede belirtilen davalar, tasarrufun yayınlandığ 1 veya davacıya bildirildiği ya da bunların yokluğunda davacı tarafından öğrenildiği günü takip eden iki ay içinde açılır."

Görüldüğü üzere, madde metni özel kişilerin davacılık koşulları bakımından devrimsel bir değişim içermemektedir.

Anayasal Antlaşma taslağında konunun düzenlenişine ilişkin bir inceleme için $b k z$. Marton Varju, "The Debate on the Future of Standing under Article 230(4) TEC in the European Convention", European Public Law, Cilt 10, 2004, s. 43-56.
} 


\section{Sonuç}

Görüldüğü üzere Avrupa Topluluğunun yarg1 organlarının (Adalet Divanı ve İlk Derece Mahkemesi) münhasır yetkisine giren davalar arasında yer alan iptal davası önemli işlevlere sahiptir. Bu dava yoluyla hem Topluluk kurumlarının bağlayıcı tasarruflarının hukuka uygunluk denetimi gerçekleştirilmekte, hem de Topluluk hukukuna hakim olan ilkelerin Divan tarafından yorumlanma ve geliştirilmesi imkanı doğmaktadır. Özellikle, düzenleme yapma ve karar alma konusunda sinırlı yetki ilkesinin hakim olduğu Toplulukta bu yetkinin sınırlarının ve çerçevesinin çizilmesi ve denetlenmesinde, dolayısıyla hem üye devletlerle Topluluk, hem de Topluluk kurumları arasındaki dengenin korunmasında iptal davası önemli bir rol oynamaktadır. Bundan başka davanın ikinci bir temel fonksiyonu bireysel hakların Topluluk düzeyinde etkili biçimde korunmasında oynadığ 1 rolde kendisini göstermektedir. Son yıllarda özellikle özel kişilerin dava açabilmesine ilişkin koşullarda daha esnek bir yaklaşım benimsenmesi gerekliliği hem doktrin, hem de Divanın kendisi tarafından zımnen, Hukuk Sözcüleri ve İlk Derece Mahkemesi tarafindan ise açıkça ortaya konmaktadır. Ancak, Divan, söz konusu gerekliliğin farkında olmakla birlikte bu yönde içtihat değişikliğinin ve kurucu antlaşmanın metninden sapan bir yorumun demokratik meşruiyet tartışmalarının damgasını vurduğu mevcut siyasi iklimde uygunsuz ve zamansız olacağı endişesini taşımaktadır. Divana göre bu alanda görev ve sorumluluk kurucu antlaşma değişikliğine yetkili olan üye devletlere aittir. 